\title{
Mesozoic phytoclast records in the Sriperumbudur (Palar Basin), Kota (Chintalapudi Sub-Basin) and Dubrajpur (Rajmahal Basin) formations, India

\author{
Registros de fitoclastos mesozoicos nas formações Sriperumbudur (Bacia de Palar), \\ Kota (Sub-bacia de Chintalapudi) e Dubrajpur (Bacia de Rajmahal), Índia
}

\author{
Sarah Gonçalves Duarte ${ }^{1}$, Neerja Jha $^{2}$, Harinam Joshi², Eliana Schwartz Tavares ${ }^{3}$, Mitsuru Arai ${ }^{4}$ and \\ Maria Dolores Wanderley ${ }^{1}$ \\ ${ }^{1}$ Universidade Federal do Rio de Janeiro - UFRJ, Departamento de Geologia, Av. Athos da Silveira Ramos, 274 \\ Cidade Universitária, Ilha do Fundão, CEP 21949-916, Rio de Janeiro, RJ, Brazil (sarahpalino@yahoo.com.br; \\ doloreswanderley@msn.com) \\ ²Birbal Sahni Institute of Palaeosciences - BSIP, Lucknow, Uttar Pradesh, India (neerjajha@yahoo.co.uk; \\ harinamjoshi@yahoo.com) \\ 3Universidade Federal do Rio de Janeiro - UFRJ, , Rio de Janeiro, RJ, Brazil (elianast@gmail.com) \\ 4Universidade Estadual Paulista "Júlio de Mesquita Filho" - UNESP, Instituto de Geociências e Ciências Exatas - IGCE, \\ Centro de Geociências Aplicadas ao Petróleo - UNESPetro, Rio Claro, SP, Brazil (mitsuru.arai@gmail.com)
}

Received on April $1^{\text {st }}, 2016$; accepted on October 10 $0^{\text {th }}, 2016$

\begin{abstract}
The studies of fossil plant cuticles in palynological samples recovered from three cored boreholes located in the Indian states of Andhra Pradesh (Kota/Gangapur Formation, Chintalapudi Sub-basin, Godavari Graben, Jurassic-Cretaceous), Tamil Nadu (Sriperumbudur Formation, Palar Basin, Upper Jurassic-lowermost Cretaceous), and Jharkhand (Dubrajpur Formation, Rajmahal Basin, Upper Jurassic-Lower Cretaceous) are presented herein. Cuticles and palynomorphs were recovered by standard palynological practices in the Gondwana Palynological Laboratory of the Birbal Sahni Institute of Palaeosciences, Lucknow, India. Fossil specimens were examined under a binocular microscope and photomicrographs were taken with a digital camera. Twenty seven morphotypes of fossil cuticles (occasionally representing stomata, trichomes and secretory structures) and other tissues (e.g., a plicate parenchyma) were recovered. The morphological analysis of cuticles and associated palynomorphs reflect the presence of different groups of plants (Bennettitales, Coniferales, Ginkgoales, Polypodiales, and Pteridospermales). In some occasions, cuticles display distinct structures (e.g., monocyclic stomata, secretory structures) that allow comparisons with some extant and fossil genera. We conclude that the study of well-preserved fossil cuticles and associated palynomorphs allow taxonomic inferences on the composition of the parent floras.
\end{abstract}

Keywords: Fossilized cuticle; Fossilized stomata; Fossilized parenchyma; Jurassic; Cretaceous; India.

\section{Resumo}

Os estudos de cutículas de plantas fósseis em amostras de três poços perfurados na Índia localizados nos estados de Andhra Pradesh (Formação Kota/Gangapur, Sub-bacia de Chintalapudi, Graben Godavari, Jurássico-Cretáceo), Tamil Nadu (Formação Sriperumbudur, Bacia Palar, Jurássico Superior-Cretáceo Inferior) e Jharkhand (Formação Dubrajpur, Bacia de Rajmahal, Jurássico Superior e Cretáceo Inferior) são apresentados aqui. Cutículas e palinomorfos foram recuperados pelo método-padrão de preparação palinológica no laboratório de Palinologia do Gondwana do Birbal Sahni Institute of Palaeosciences, Lucknow, Índia. Espécimes fósseis foram examinados com microscópio óptico binocular, e fotomicrografias foram obtidas com câmera digital. Vinte e sete morfotipos de cutículas fósseis (ocasionalmente representando estômatos, tricomas e estruturas secretoras) e outros tecidos (ex.: parênquima plicado) foram recuperados. A análise morfológica das cutículas e dos palinomorfos associados refletem a presença de diferentes grupos de plantas (Bennettitales, Coniferales, Ginkgoales, Polypodiales e Pteridospermales). As cutículas exibem distintas estruturas (ex.: estômatos ciclocíticos e estruturas secretoras) que permitem comparações com plantas atuais e fósseis. Conclui-se que o estudo das cutículas fósseis bem preservadas e dos palinomorfos associados permitem inferências taxonômicas na composição das floras-mãe.

Palavras-chave: Cutícula fossilizada; Estômatos fossilizados; Parênquima fossilizado; Jurássico; Cretáceo; Índia. 


\section{INTRODUCTION}

Several scientific reports are documented on the occurrence of phytoclasts (plant cuticles and tissues) in Indian basins (Godavari, Palar and Rajmahal). The present work focuses on the phytoclast analysis of some Mesozoic sediments from three basins namely, Kota/Gangapur Formation of Chintalapudi
Sub-basin of Godavari Basin located in the State of Andhra Pradesh; Sriperumbudur Formation of Palar Basin, located in the State of Tamil Nadu (both situated in Southern India) and Dubrajpur Formation of Rajmahal Basin, located in the State of Jharkhand (North eastern India), which enabled to draw taxonomic inferences and understand the composition of fossil flora of these deposits (Figure 1).

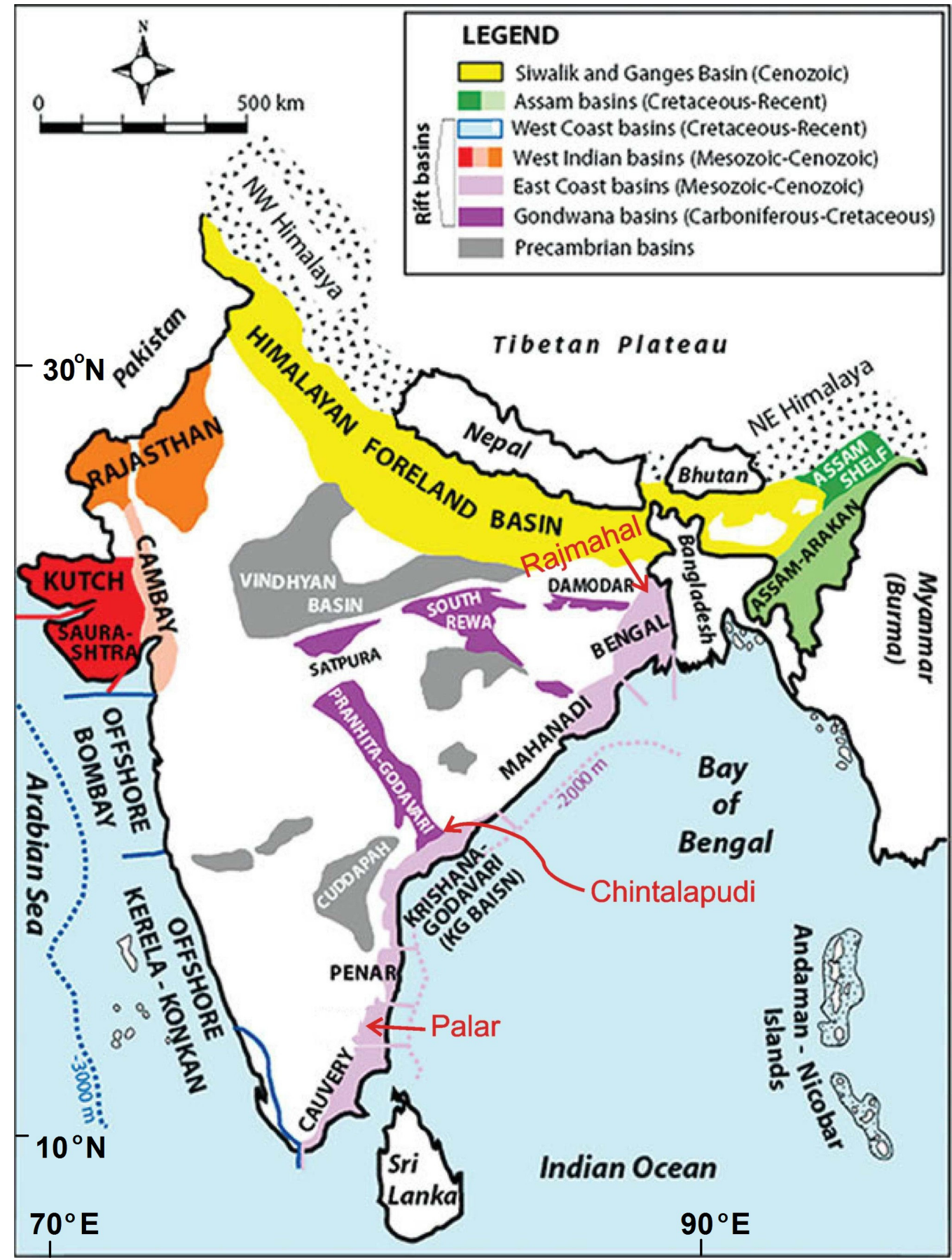

Figure 1. Sedimentary basins of India (modified from Sorkhabi, 2008) showing the locations of Chintalapudi Sub-basin, Palar Basin and Rajmahal Basin. 
Plant tissue records are quite common in the sedimentary basins where palynological samples are collected. These samples are macerated by standard palynological preparation aiming to increase the concentration of organic-walled microfossils in the residue. From the sequences of the present study, a large number of cuticles were recovered with or without stomata and trichomes, some secretory structures and also parenchymatous tissues. Epiderm is an outer covering tissue of plant organs in the primary structure, being replaced by new periderm in growth organ with secondary growth (Esau, 1977). Since epiderm is in direct contact with the external prevailing environment, it is highly susceptible to modifications in various features such as structure, composition, function and their origin or extinction. Plant appendages, the trichomes, which are found in the plant epiderm (Fahn, 1990) are also examined in the subjected study material. In general, fossil epiderm is represented only by cuticle, which is the upper part of epiderm, constituted by a layer without cellular material (Metcalfe and Chalk, 1979) that covers the mature and aerial parts of plants. Cuticles consist predominantly of cutin, a lipid component that is resistant to degradation.

Since the last few decades, there has been a lot of published scientific literature pertaining to plant tissues from palynological preparations and their pivotal importance (Lakhanpal, 1945; Sitholey et al., 1954; Kovach and Dilcher, 1984; Dev and Rajanikanth, 1988; Tewari et al., 2001; Khar and Singh, 2003; Duarte and Arai, 2008, 2010; Arai and Duarte, 2010). The studies concerning plant tissue records in the Chintalapudi Sub-basin are very scarce, because the Mesozoic sequence of this sub-basin was little studied until now.

Some plant tissues and several kinds of cuticles are found in palynological residues. These are under rigorous studies in detail and can find the elemental key role in biostratigraphic and palaeoclimatic studies (Kovach and Dilcher, 1984). Besides providing an effective tool for palaeoenvironmental reconstruction, they also develop the understanding of evolutionary history of a taxon. Taxonomic inferences have been established by analyzing various cuticles incorporating well preserved stomata (Kovach and Dilcher, 1984).

Cuticles of Miocene age from Poland have also been used to solve the biostratigraphic problems to some extent (Juchniewicz, 1975). Cuticle studies by Anzotegui (1980), led to the results about possible depositional age of sediments containing studied plant tissues.

Besides microscopic studies of tissues and cuticles in palynological preparations, these are also investigated in well preserved plant megafossils in the form of impressions. This is important from the view of comparisons of plant tissues recovered in palynological slides and precisely well identified plant megafossil cuticle or tissue impressions. This will be of crucial significance in order to establish botanical affinities and moreover to set the path of comparison with extant plants.
Lakhanpal (1945) dated sediments from samples of northern Bhander Kas, Khewra and from southern Pharwala section of the Mayo Salt Mine, Khewra (Pakistan) which are not older than middle Mesozoic by studying preserved tissues, vessels, wood and log having preserved structures of Gymnosperms and Angiosperms.

Tewari et al. (2001) demonstrated that tissues and cuticle studies can also be applied to determine the degree and stage of maturation of preserved organic matter in sediments.

\section{GEOLOGY OF THE STUDY AREAS}

\section{Geology of the Chintalapudi Sub-basin}

The Chintalapudi Sub-basin is represented by southeastern extension of Kothagudem Sub-basin of Godavari graben that is one of the largest Indian basins (Figure 1). The Godavari graben contains also the Godavari sub-basin and KrishnaGodavari coastal tract. The stratigraphic column of Chintalapudi sub-basin is constituted by two large sequences: Lower Gondwana and Upper Gondwana. The Lower Gondwana is composed by Talchir (Permian), Barakar (Permian) and Kamthi (late Permian-Lower Triassic) formations, and it has already been well studied (Jha, 2008; Jha et al., 2012, 2014), whereas Upper Gondwana of this sub-basin, composed by Juro-Cretaceous Maleri, Kota and Gangapur formations, is relatively little studied.

The studied samples of this sub-basin come from the Kota/Gangapur Formation.

\section{Geology of Palar Basin}

The Palar Basin, with $36,000 \mathrm{~km}^{2}$, is located in the southern India (Figure 1). According to Lal et al. (2009), its stratigraphic column is constituted by following units: Pundi Shale (Permo-Triassic), Sriperumpudur Formation (Upper Jurassic-basal Cretaceous), Satyavadu Formation (Aptian), Tirupati Sandstone Formation (Upper Cretaceous), Paleogene undifferentiated unit and the Cuddalore Sandstone (Neogene).

The studied samples of Palar Basin come from Sriperumpudur Formation.

\section{Geology of Rajmahal Basin}

The Rajmahal Basin covers an area of $10,000 \mathrm{~km}^{2}$ and constitutes a part of "Rajmahal Malda-Purnea master basin" in northeastern India (Figure 1).

Its stratigraphic column is constituted by following units: Barakar and Raniganj formations, from Permian; "infra-trap" unit of Dubrajpur Formation, Upper Triassic; Upper Dubrajpur unit, Upper Jurassic - Lower Cretaceous; 
trap and inter-trap units of Rajmahal Formation, Lower Cretaceous (Banerji, 2000). The inter-trap unit of Rajmahal Formation was dated radiometrically as $117 \mathrm{Ma}$, Aptian (Srivastava and Krassilov, 2012).

The single studied sample of this basin has been collected from Dubrajpur Formation.

\section{MATERIALS AND METHOD}

The palynological samples were obtained from Jurassic-Cretaceous interval of the Kota/Gangapur Formation (Chintalapudi Sub-basin), Dubrajpur (Rajmahal Basin) and Sriperumbudur (Palar Basin) formations (see Appendix). These samples came from boreholes drilled in these basins. The samples were macerated in the laboratory of the palynological preparation of the Birbal Sahni Institute of Palaeosciences (Lucknow, India) by standard palynological techniques: $10 \mathrm{~g}$ of each sample from the boreholes with different lithological types were macerated and processed with $40 \% \mathrm{HF}$ to dissolve the inorganic matter, then they were cleaned with water many times to remove the acid and unwanted substances. Then the samples were processed with nitric acid $\left(\mathrm{HNO}_{3}\right)$ for 3 days shaking frequently aiming to break the humic organic matter. After nitric acid oxidation, the acid was decanted and the samples were cleaned with distilled water. Then the samples were processed with $10-20 \%$ potassium hydroxide $(\mathrm{KOH})$ aiming to clean the palynomorphs. The slides were mounted using Canada balsam and Polyvinyl Chloride. All cuticles and tissues preserved in the slides were analyzed, counted and measured at Olympus BX62 Microscope and photographed with the DP25 camera.

\section{RESULTS AND DISCUSSION}

Twenty seven morphotypes of phytoclasts were recorded, including cuticles and other types of plant tissues. Many of them are stomata-bearing cuticles.

\section{Description of phytoclast morphotypes}

For the phytoclast description, the following abbreviations were applied: L= Length; $\mathrm{W}=$ Width; $\mathrm{EF}=$ England Finder coordinate.

The 27 phytoclast morphotypes can be arranged, grosso modo, in 5 groups for convenience in studies:

Cuticles with epidermic cell impression bearing stomata (Phytoclasts 1 to 16); cuticle with papillary epidermal cell with trichomes (Phytoclasts 17 and 18); cuticle with secretory structure (resin duct, Phytoclast 19); Cuticle with only epidermal cell impression (Phytoclasts 20 to 26); and filling tissue - parenchyma (plicate parenchyma, Phytoclast 27).

A-Cuticles with epidermal cells and stomata

Phytoclast 1 (Figure 2A)
Occurrence: slide 37.

Description. Cuticles with rows of long epidermal cells and slightly sinuous anticlinal walls, escorted laterally by a row of stomata. This fragment looks like epiderm of needles of Pinus sp. (Figure 2A), which is similar to the Pinus tissue illustrated by Fahn (1985) (Figure 2B).

Dimensions. Size of cuticle fragment - $\mathrm{L}=310 \mu \mathrm{m}$, $\mathrm{W}=275 \mu \mathrm{m}$; Average size of cells $-\mathrm{L}=40 \mu \mathrm{m}, \mathrm{W}=20 \mu \mathrm{m}$; Size of stoma apparatus - $\mathrm{L}=35 \mu \mathrm{m}, \mathrm{W}=25 \mu \mathrm{m}$.
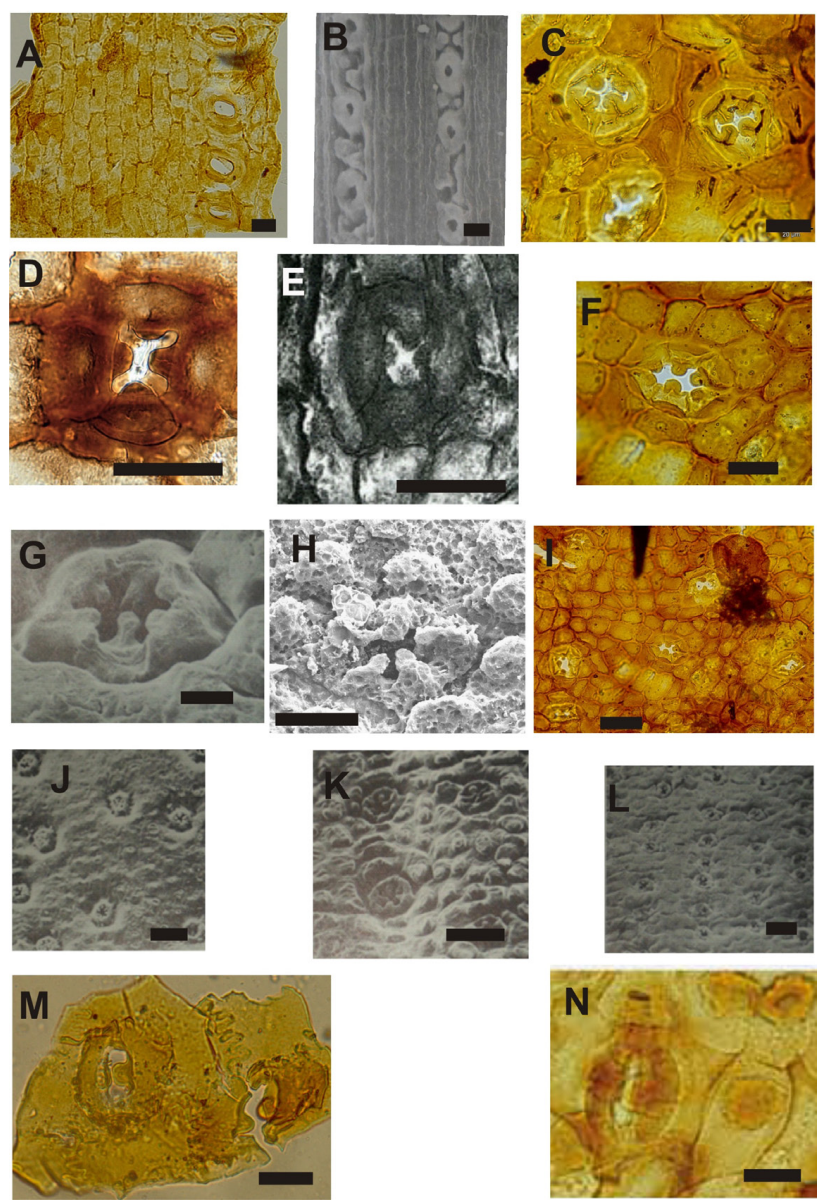

Figure 2. A - Phytoclast 1 Cuticle (Slide 37, EF= Q62/1). B - Epiderm of acicule of Pinus sp. (in Fahn, 1985), similar to Phytoclast 1. C - Phytoclast 2 Cuticle (Slide 51.1, $\mathrm{EF}=\mathrm{K} 30 / 2$ ). D - Stoma of Frenelopsis (in Taylor et al., 2009) with affinity for Phytoclast 2. E - Stomata of Quadrocladus (in Pflanzenfossilien, 2012) morphologically similar to Phytoclast 2. F, I - Phytoclast 3 Cuticle (Slide 51.2, EF=X65/2). G, $\mathbf{J}, \mathbf{L}$ - Stomata of genus Pseudofrenelopsis (in Watson, 1977) with affinity for Phytoclast 3. H - Stomata of genus Pseudofrenelopsis (in Yang et al., 2009) with affinity for Phytoclast 3. K - Stomata of fossil genus Frenelopsis (in Watson, 1977) with affinity for Phytoclast 3 of figure 2-I. M - Phytoclast 4 Cuticle (Slide 7, EF= J 51/2). N - Stomata of fossil genus Nilssoniopteris (in Pott and Krings, 2010) with affinity for Phytoclast 4. Scale bar $=20 \mu \mathrm{m}, \mathrm{EF}=$ England Finder coordinates. 
Palynological association. Araucariacites pollen grains were found predominant in this slide and besides these many bisaccate grains and Callialasporites were recorded. These grains indicate cold climate and are related to Gymnosperms. This supports the possibility of the tissues to be assigned to Order Coniferales.

Probable botanical affinity. Pinus Linnaeus (Coniferales - Pinaceae).

Stratigraphic range. Triassic to Recent.

$$
\text { Phytoclast } 2 \text { (Figure 2C) }
$$

Occurrence: slide 51.1.

Description. Cuticle with epidermal cell impressions display irregular and variable cell forms having straight and thick anticlinal walls. Stomata are similar to monocyclic type, regularly distributed, forming depressions. Some stomatal apertures are covered by four papillae. Each stomatal apparatus has about five strongly cutinized subsidiary cells (Figure 2C). Tissues similar to given phytoclast are illustrated in Figures 2D and 2E by Taylor et al. (2009) and Pflanzenfossilien (2012) respectively.

Dimensions. Size of cuticle fragment - $\mathrm{L}=110 \mu \mathrm{m}$, $\mathrm{W}=145 \mu \mathrm{m}$; Average size of cells $-\mathrm{L}=30 \mu \mathrm{m}, \mathrm{W}=25 \mu \mathrm{m}$; Size of stoma apparatus - $\mathrm{L}=40 \mu \mathrm{m}, \mathrm{W}=38 \mu \mathrm{m}$; Size of papilla of stoma $-\mathrm{L}=8 \mu \mathrm{m}, \mathrm{W}=9 \mu \mathrm{m}$.

Palynological association. Araucariacites is the predominant element of palynological assemblage in association with different species of Callialasporites and bisaccate pollen grains. This palynoassemblage indicates cold paleoclimate which favoured luxuriant growth of the group of Gymnosperms. This has strengthened the possibility of the relation of studied tissue with spermatophyta groups cited below (e.g., Coniferales). A number of smooth trilete spores are also reported in the palynological sample.

Probable botanical affinity. Frenelopsis Schenk emend. Reymanówna and Watson Fontaine (Coniferales Cheirolepidiaceae)

Stratigraphic range. Upper Jurassic to Upper Cretaceous.

Remarks. The stomata of this phytoclast looks like Quadrocladus K. Mädler (Voltziales). But according to the stratigraphic provenance this possibility is neglected, since Quadrocladus is a Permian genus while analyzed samples are dated as Jurassic-Cretaceous (Figure 2E).

\section{Phytoclast 3 (Figures 2F and 2I)}

Occurrence: slide 51.2.

Description. Cuticle expressed epidermal cells with diverse and irregular shapes without papillae. Stomata are similar to monocyclic type, aligned in irregular lines, having five to six subsidiary cells bearing papillae (Figures $2 \mathrm{~F}$ and 2I). Watson (1977) and Yang et al. (2009) illustrated cuticles with stomata very similar to those found in Phytoclast 3 (Figures 2G, 2H, 2J, 2K and 2L).

Dimensions. Cuticle fragment size - $\mathrm{L}=325 \mu \mathrm{m}$, $\mathrm{W}=480 \mu \mathrm{m}$; Average cell size $-\mathrm{L}=25 \mu \mathrm{m}, \mathrm{W}=18 \mu \mathrm{m}$; stomatal apparatus size of - $\mathrm{L}=50 \mu \mathrm{m}, \mathrm{W}=35 \mu \mathrm{m}$; Stomatal papilla size $-\mathrm{L}=10 \mu \mathrm{m}, \mathrm{W}=15 \mu \mathrm{m}$.

Palynological association. Pollen grains with predominating Araucariacites are found associated with many bisaccate pollen grains and Callialasporites that are indicators of cold climate and related to Gymnosperms. This elaborates the possibility of Phytoclast 3 to be related to spermatophyta cited below (Coniferales).

Probable botanical affinity. Frenelopsis Schenk emend. Reymanówna and Watson Fontaine (Coniferales-Cheirolepidiaceae); Pseudofrenelopsis Nathorst (Coniferales-Cheirolepidiaceae).

Stratigraphic range. Upper Jurassic to Upper Cretaceous. Phytoclast 4 (Figure 2M)

Occurrence: slide 7.

Description. Cuticle with epidermal cells having very sinuous wall and paracytic stomata. The subsidiary cells are slightly more cutinized than common cells of epiderm containing papillae, one in each, facing the ostiole. Pott and Krings (2010) described cuticle with similar stomata in Nilssoniopteris (Bennettitales) (Figure 2N).

Dimensions. Size of cuticle fragment - $\mathrm{L}=125 \mu \mathrm{m}$, $\mathrm{W}=75 \mu \mathrm{m}$; Average size of cells - $\mathrm{L}=40 \mu \mathrm{m}, \mathrm{W}=30 \mu \mathrm{m}$; Size of stoma apparatus - $\mathrm{L}=32 \mu \mathrm{m}, \mathrm{W}=30 \mu \mathrm{m}$; Size of papilla of stoma $-\mathrm{L}=5 \mu \mathrm{m}, \mathrm{W}=7 \mu \mathrm{m}$.

Palynological association. Bisaccate pollen grains associated to Pinales predominantly mark their presence in this sample which are indicators of temperate and cold climate. Furthermore, a large population of Araucariacites and Callialasporites supports the view and indicate cold climate with affinity for Gymnosperms.

Probable botanical affinity. Nilssoniopteris Nathorst (Bennettitales) (Figure 2N).

Stratigraphic range. Middle Triassic to Lower Cretaceous. Phytoclast 5 (Figures 3A and 3B)

Occurrence: slides 13 and 19.

Description. Cuticle with irregular polygonal cells and variable size, with anticlinal, thick, curved to straight walls. Stomatal apparatus similar to dicyclic, with stomatal cells below the level of the subsidiary cells. Trapezoidal subsidiary cells in number of 4 to 8 , with thick walls, especially the walls near to pore. Papillae can be observed in the common cells of epiderm (Figures 3A and 3B).

Dimensions. Size of cuticle fragment - $\mathrm{L}=480 \mu \mathrm{m}$, $\mathrm{W}=270 \mu \mathrm{m}$; Average size of cells $-\mathrm{L}=45 \mu \mathrm{m}, \mathrm{W}=45 \mu \mathrm{m}$; Size of stoma apparatus- $\mathrm{L}=55 \mu \mathrm{m}, \mathrm{W}=53 \mu \mathrm{m}$

Palynological association. Pollen grains assemblage is characterized by predominating Araucariacites and good number of bisaccate pollen grains and Callialasporites observed in slide 13, while slide 19 has bisaccate grains as major palynological constituents, and Araucariacites, Callialasporites are also recorded in abundance. In both the slides, there is the integrated predominance of grains that are indicators of temperate climate. These observed grains 

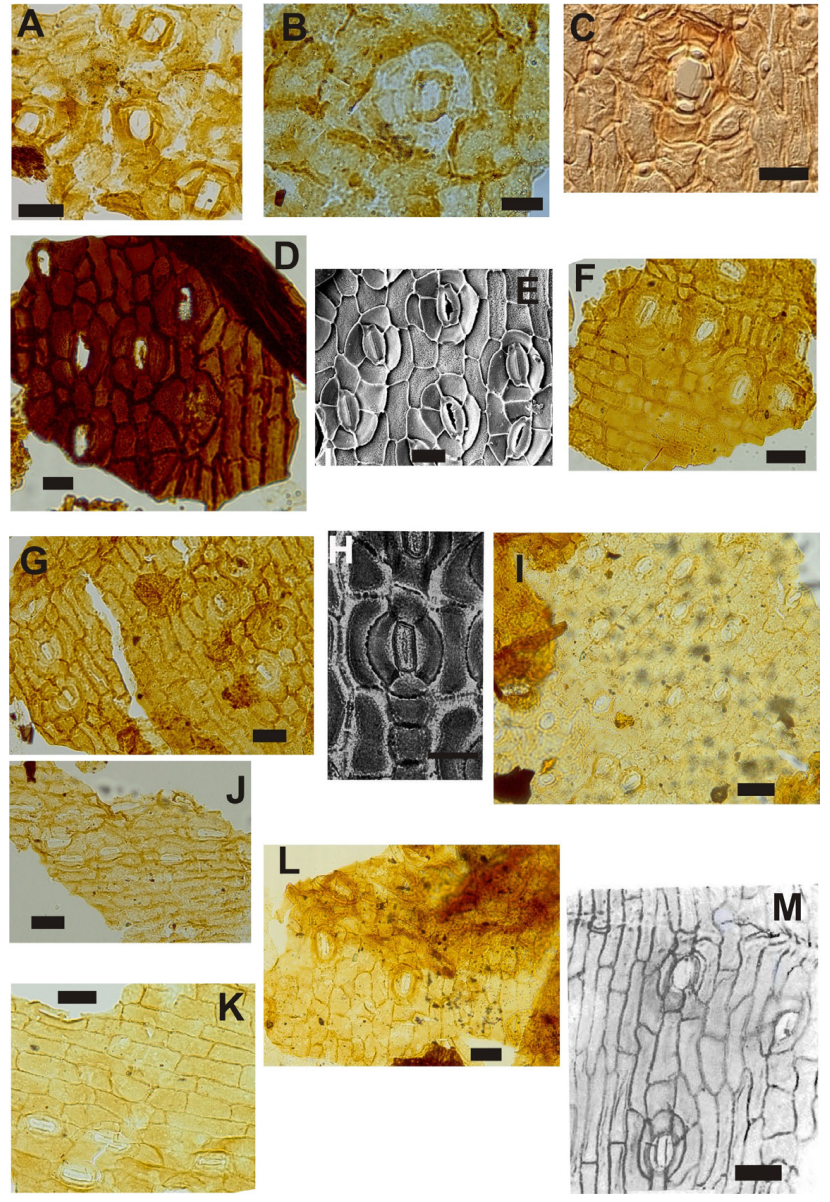

Figure 3. A - Phytoclast 5 Cuticle (Slide 13, EF = O44/4). B - Phytoclast 5 Cuticle (Slide 19, EF = O59). C - Epiderm of Ortisea (in Universitat Muenster, 2014) with stoma and papillae that has affinity with Phytoclast 5. D - Phytoclast 6 Cuticle with stomata (Slide 52, EF=W 61/2). E - Cuticle with stomata of fossil genus Cryptomeria (in Ma et al., 2007) similar to Phytoclast 6. F - Phytoclast 7 Cuticle (Slide 20, $E F=P 43-2)$. G - Phytoclast 8 Cuticle (Slide 30, EF=Y34). $\mathbf{H}$ - Stoma of genus Cephalotaxus (in Watson and Dallwitz, 2009), with affinity for Phytoclast 8 . I - Phytoclast 9 Cuticle (Slide 61, EF= H67). J - Phytoclast 9 Cuticle (Slides 19, $\mathrm{EF}=\mathrm{R} 65 / 2$ ). K - Phytoclast 9 Cuticle (Slide 18, EF=Q65). L - Phytoclast 9 Cuticle (Slide 13, EF=F58/1). M - Fossil cuticle of Enormicutis torquata (in Kovach and Dilcher, 1984), that has affinity with Phytoclast 9. Scale bar $=20 \mu \mathrm{m}$, $\mathrm{EF}=$ England Finder coordinates.

are related to Gymnosperms. This reinforces the possibility that studied tissues are related with Gymnosperms, mainly Pinophyta which is represented by bisaccate pollen grains in the associated palynological assemblage. The tissue of Ortiseia, a conifer (Figure 3C) is illustrated in the Palaeobotany collection site of Muenster University (Universitat Muenster, 2014) that is looking similar to Phytoclast 5. However, Ortisea is exclusively observed in Paleozoic (Pennsylvanian to Lower Permian), hence the botanical affinities with Ortisea is discarded, because the samples of present work belongs to Jurassic-Cretaceous age.

Botanical affinity. Unknown.

Stratigraphic range. Unknown.

$$
\text { Phytoclast } 6 \text { (Figure 3D) }
$$

Occurrence: slide 52 .

Description. Cuticles consisted of cells with straight anticlinal walls and showing rows of elongated cells escorted laterally by portion of cells tending to be isodiametric, triangular or polygonal. Their stomata are similar to monocyclic type, exhibiting elliptical pores. The subsidiary cells are about five in number and most of them show trapezoidal shape and an elevation above the plane of the cuticle. In one of the stomatal apparatus one papilla is present pointed toward the opening pore of stomata (Figure 3D). Similar cuticle was recorded in Cryptomeria (Figure 3E) by Ma et al. (2007).

Dimensions. Cuticle fragment size - L $=190 \mu \mathrm{m}, \mathrm{W}=190 \mu \mathrm{m}$; Average cell size- $\mathrm{L}=45 \mu \mathrm{m}, \mathrm{W}=12 \mu \mathrm{m}$; Stomatal apparatus size $-\mathrm{L}=60 \mu \mathrm{m}, \mathrm{W}=40 \mu \mathrm{m}$.

Palynological association. Pollen grains associated with Araucariacites are found. Many bisaccate pollen grains and Callialasporites mark their presence. They indicate cold paleoclimate and are related to Gymnosperms. In general, bisaccate grains are associated with Pinales. This enhances the possibility of association of recovered tissue with Coniferales.

Probable botanical affinity. Cryptomeria Thunberg ex Linnaeus (Coniferales-Cupressaceae) (Figure 3E).

Stratigraphic range. Triassic to Recent.

Phytoclast 7 (Figure 3F)

Occurrence: slide 20.

Description. Cuticle with predominantly elongated epidermal cell impressions having straight walls are arranged in uniseriate rows escorting laterally to portions of cells tending to polygonal shape. Stomatal apparatus similar to cyclocytic type also occur arranged in rows. Between them, in the same arrangement, elongated cells can occur perpendicularly to those cells in the regions devoid of stomata.

Dimensions. Size of cuticle fragment - $\mathrm{L}=280 \mu \mathrm{m}$, $\mathrm{W}=340 \mu \mathrm{m}$; Average size of cells - $\mathrm{L}=12 \mu \mathrm{m}, \mathrm{W}=20 \mu \mathrm{m}$; Size of stoma apparatus- $\mathrm{L}=75 \mu \mathrm{m}, \mathrm{W}=50 \mu \mathrm{m}$.

Palynological association. Bisaccate pollen grains are found predominating. Furthermore, large number of Araucariacites and Callialasporites are present, indicating cold paleoclimate and they are related to Gymnosperms. In general, bisaccates are associated with Pinales. This improves the possibility of tissue found to be associated with Gymnosperms.

Botanical affinity. Gymnosperm indet.

Stratigraphic range. Unknown.

$$
\text { Phytoclast } 8 \text { (Figure 3G) }
$$

Occurrence: slide 30 .

Description. Cuticle showing cell impressions with straight and slightly sinuous walls. On tissue surface, areas of elongated cells are alternated with areas having stomata 
arranged in linear fashion and cells tending to be isodiametric. The stomatal apparatus are showing similarity to dipolar parahexacytic type by sharing single cell at their poles.

Dimensions. Cuticle fragment size - $\mathrm{L}=500 \mu \mathrm{m}$, $\mathrm{W}=480 \mu \mathrm{m}$; Average cell size $-\mathrm{L}=75 \mu \mathrm{m}, \mathrm{W}=12 \mu \mathrm{m}$; Stomatal apparatus size- $\mathrm{L}=45 \mu \mathrm{m} \mathrm{W}=45 \mu \mathrm{m}$.

Palynological association. Pollen grains of Araucariacites are reported. Presence of bisaccate grains and Callialasporites indicate temperate and cold climate and having link with Gymnosperm. These factors support the possibility of cuticles' relation with Gymnosperms. Bisaccate pollen grains again reinforces their association with Coniferales.

Probable botanical affinity. Cephalotaxus Siebold and Zuccarini ex Endlicher (Coniferales -Taxaceae) (Figure 3H).

Stratigraphic range. Jurassic to Recent.

Phytoclast 9 (Figures 3I, 3J, 3K and 3L)

Occurrences: slides 13, 18, 19 and 61.

Description. Cuticle revealing cells with straight walls. Rows of elongated rectangular cells in frontal view which are alternated with line of shorter and polygonal cells with straight to curved walls. They are alternated with stomatal apparatus similar to cyclocytic type. The subsidiary cells are more cutinized than the rest of the epidermal cells.

These cuticles are very similar to those found in the Eocene of North America and classified by Kovach and Dilcher (1984) as Enormicutis torquata (Figure 3M), but they were not considered herein because of its stratigraphic incompatibility.

Dimensions. Size of cuticle fragment $-\mathrm{L}=512 \mu \mathrm{m}$, $\mathrm{W}=525 \mu \mathrm{m}$; Average size of cells of tissue $-\mathrm{L}=50 \mu \mathrm{m}$, $\mathrm{W}=12 \mu \mathrm{m}$; Size of stoma apparatus- $\mathrm{L}=25 \mu \mathrm{m} \mathrm{W}=20 \mu \mathrm{m}$.

Palynological association. Pollen grains of Araucariacites are represented in majority with bisaccates and Callialasporites in slide 13. In the slide 61, besides Araucariacites, bisaccate pollen and Callialasporites are predominant constituents. In both slides, the integrated predominance of temperate climate palynomorphs is noticeably high. All of these grains are related to Gymnosperms.

Botanical affinity. Gymnosperm indet.

Stratigraphic range. Unknown.

Phytoclast 10 (Figures 4A and 4B)

Occurrences: slides 19 and 33.

Description. Cuticles having cells with straight to curved anticlinal walls. Cells elongate to isodiametric, the last ones being papillae-bearing. Stomata with four subsidiary cells, two being parallel to stomatal cells and two in polar position to stoma, similar to tetracytic type. The stomatal apparatus are often very close each other and the areas containing stomata are alternated with areas devoid of stomata, where cells with elongated walls and papillae occur.

Dimensions. Size of cuticle fragment - $\mathrm{L}=325 \mu \mathrm{m}$, $\mathrm{W}=230 \mu \mathrm{m}$; Average size of cells $-\mathrm{L}=22 \mu \mathrm{m}, \mathrm{W}=6 \mu \mathrm{m}$; Size of stoma apparatus- $\mathrm{L}=30 \mu \mathrm{m}, \mathrm{W}=20 \mu \mathrm{m}$.
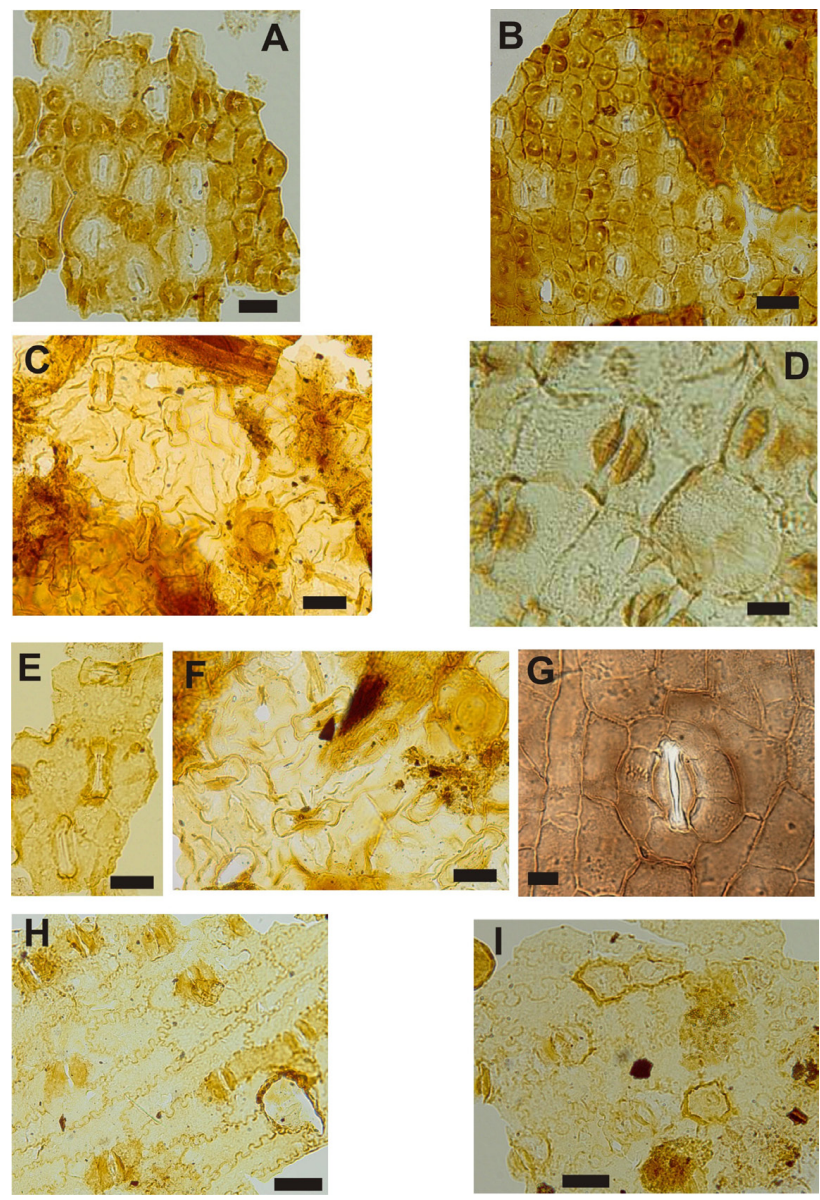

Figure 4. A - Phytoclast 10 Cuticle (Slide 19, EF = Q68/1). B - Phytoclast 10 Cuticle (Slide 33, $E F=L 43 / 3$ ). C, F - Phytoclast 11 Stomatal structures (Slide 13, EF= 047/2). D - Stomata of fossil genus Dycroidium (in Taylor et al., 2009) with affinity for stomata of Phytoclast 11. E - Phytoclast 11 Stomatal structures (Slide 27, EF= L47). G - Stomata of fossil genus Sphenophylum (in Taylor et al., 2009) with affinity for stomata of Phytoclast 11. H - Phytoclast 12 Cuticle (Slide 28, EF=U61). I - Phytoclast 13 Cuticle (Slide 19, EF= L66). Scale bar $=20 \mu \mathrm{m}, E F=$ England Finder coordinates .

Palynological association. Araucariacites pollen grains are predominant, in association with bisaccates and Callialasporites in the slide 33. In the slide 19 bisaccate pollen grains are predominant, but Araucariacites and Callialasporites are also represented. Hence palynomorphs in both the slides indicate temperate climate and are related to Gymnosperms. Both slides represented smooth and ornamented trilete spores and some unidentified pollen grains are also found. However, the recorded phytoclasts do not seem to have affinity with most of the palynomorphs having relation with Gymnosperm.

Botanical affinity. Unknown.

Stratigraphic range. Unknown.

Phytoclast 11 (Figures 4C, 4E and 4F) 
Occurrence: slides 13 and 27.

Description. Stomatal apparatus slightly distinct with halter shape, surrounded by epidermal cells. According to Taylor et al. (2009), these halter-shaped stomatal structures are present in the genus Dicroidium (Pteridospermatophyta - Pteridospermales - Corystospermaceae) (Figure 4D) and Sphenophyllum (Sphenophyta - Sphenophyllales) (Figure 4G). However, as these genera are extinct in the Triassic, their botanical affinities are nullified, because the Phytoclast 11 pertains to Jurassic-Cretaceous strata.

Dimensions. Cuticle fragment size - $\mathrm{L}=360 \mu \mathrm{m}$, $\mathrm{W}=380 \mu \mathrm{m}$; Average cell size $-\mathrm{L}=33 \mu \mathrm{m}, \mathrm{W}=35 \mu \mathrm{m}$; Stomatal apparatus size - $\mathrm{L}=35 \mu \mathrm{m}, \mathrm{W}=10 \mu \mathrm{m}$.

Palynological association. Predominating Araucariacites pollen grains with many bisaccate grains and Callialasporites are present in slide 13. Slide 27 contains bisaccate pollen grains, Araucariacites and Callialasporites in predominance. Both slides represent predominance of temperate climate palynological constituents. Recorded palynomorphs are signaling relation of phytoclast with Gymnosperms. Smooth and ornamented trilete spores, Cicatricosisporites, Contignisporites and some unidentified pollen grains are also recorded in these investigated slides.

Botanical Affinity. Unknown.

Stratigraphic range. Unknown.

$$
\text { Phytoclast } 12 \text { (Figure 4H) }
$$

Occurrence: slide 28 .

Description. Tissues exhibit elongated cells having very sinuous anticlinal walls. Areas containing stomata alternated with areas without stomata. Stomata similar to amphibrachyparacytic type and disposed in lines. The stomatal aperture is elongated and subsidiary cells are more cutinized, having its greater axis perpendicular to normal cells of epiderm.

Dimensions. Size of cuticle fragment - $\mathrm{L}=550 \mu \mathrm{m}$, $\mathrm{W}=390 \mu \mathrm{m}$; Average size of cells $-\mathrm{L}=100 \mu \mathrm{m}, \mathrm{W}=40 \mu \mathrm{m}$; Wave length and width of sinuosity - $\mathrm{L}=5 \mu \mathrm{m}, \mathrm{W}=6 \mu \mathrm{m}$; Size of stoma apparatus- $\mathrm{L}=48 \mu \mathrm{m}, \mathrm{W}=30 \mu \mathrm{m}$; Size of guard cell - $\mathrm{L}=30 \mu \mathrm{m}, \mathrm{W}=20 \mu \mathrm{m}$.

Palynological association. Bisaccate pollen grains are found in predominance. Araucariacites and Callialasporites are also present in palynocomposition. Thus, there is a predominance of temperate climate indicator palynomorphs. These grains are related to Gymnosperms. Smooth and ornamented triletes, Cicatricosisporites, Contignisporites and some unidentified pollen grains are also recovered.

Botanical affinity. Unknown.

Stratigraphic range. Unknown.

Phytoclast 13 (Figure 4I)

Occurrence: slide 19.

Description. Tissue with elongated cells, very sinuous anticlinal wall. This sinuosity is similar to that of the phytoclast described above, however, somewhat wider. Stomata containing epidermal areas are alternated with non-stomata areas in epidermis. Stomata similar to amphibrachyparacytic type arranged in a row. The stomatal aperture is elongated and subsidiary cells are more cutinized and have major axis perpendicular to the ordinary cells of the epidermis.

Dimensions. Cuticle fragment size - $\mathrm{L}=300 \mu \mathrm{m}, \mathrm{W}=275 \mu \mathrm{m}$; Average cell size - $\mathrm{L}=90 \mu \mathrm{m}, \mathrm{W}=25 \mu \mathrm{m}$; Wave length and width of sinuosity $-\mathrm{L}=5 \mu \mathrm{m}, \mathrm{W}=5 \mu \mathrm{m}$; Stomata apparatus size - $\mathrm{L}=30 \mu \mathrm{m}, \mathrm{W}=40 \mu \mathrm{m}$; Guard cell size $-\mathrm{L}=20 \mu \mathrm{m}$ $\mathrm{W}=5 \mu \mathrm{m}$.

Palynological association. Bisaccate pollen grains are found predominant. Araucariacites, Callialasporites and Aequitriradites are recorded. On the basis of predominant grains, temperate paleoclimate is deciphered. Stratigraphically significant smooth and ornamented trilete spores, Cicatricosisporites, Contignisporites and some unidentified pollen grains are also observed.

Botanical affinity. Unknown.

Stratigraphic range. Unknown.

$$
\text { Phytoclast } 14 \text { (Figure 5A) }
$$

Occurrence: slide 12 .

Description. Cuticle with epidermal cells having sinuous anticlinal walls. Desmocytic stomata are with very thick walls facing the ostiole.

Dimensions. Cuticle fragment size $-\mathrm{L}=230 \mu \mathrm{m}, \mathrm{W}=400 \mu \mathrm{m}$; Average cell size - $\mathrm{L}=25 \mu \mathrm{m}, \mathrm{W}=25 \mu \mathrm{m}$; Wave length and Sinuosity width - $\mathrm{L}=6 \mu \mathrm{m}, \mathrm{W}=6 \mu \mathrm{m}$; Stomatal apparatus size - $\mathrm{L}=50 \mu \mathrm{m}, \mathrm{W}=50 \mu \mathrm{m}$; stomatal guard cell size - $\mathrm{L}=10 \mu \mathrm{m}$, $\mathrm{W}=3 \mu \mathrm{m}$; Subsidiary cell size $-\mathrm{L}=20 \mu \mathrm{m}, \mathrm{W}=12 \mu \mathrm{m}$.

Palynological association. Predominating Araucariacites pollen grains are found with many bisaccates and Callialasporites and indicate temperate paleoclimate. Smooth as well as ornamented trilete spores, Contignisporites have marked their presence in the palynoassemblage. The trilete spores are having absolute affinity with Pteridophyta or Bryophyta.

Botanical affinity. Unknown.

$$
\text { Phytoclast } 15 \text { (Figure 5B) }
$$

Occurrence: slide 28.1 .

Description. Black cuticle with anisocytic stomatal apparatus which shares subsidiary cells. Stomatal cells with periclinal walls very cutinized in the region near pore aperture.

Dimensions - Size of cuticle fragment - $\mathrm{L}=143 \mu \mathrm{m}$, $\mathrm{W}=10 \mu \mathrm{m}$; Average size of cells $-\mathrm{L}=55 \mu \mathrm{m}, \mathrm{W}=30 \mu \mathrm{m}$; Wave length and width of sinuosity $-\mathrm{L}=12 \mu \mathrm{m}, \mathrm{W}=4 \mu \mathrm{m}$; Size of stoma apparatus - $\mathrm{L}=30 \mu \mathrm{m}, \mathrm{W}=25 \mu \mathrm{m}$; Size of guard cell of stoma $-\mathrm{L}=30 \mu \mathrm{m}, \mathrm{W}=10 \mu \mathrm{m}$.

Palynological association. Bisaccate pollen grains are found predominating along with large number of Araucariacites and Callialasporites, that are related to Gymnosperms and indicator of temperate to cold climate. This enhances the possibility of relation of this tissue with Gymnosperms. Cicatricosisporites and Contignisporites with pteridophytic origin are also represented in palynological components in the studied slide. 


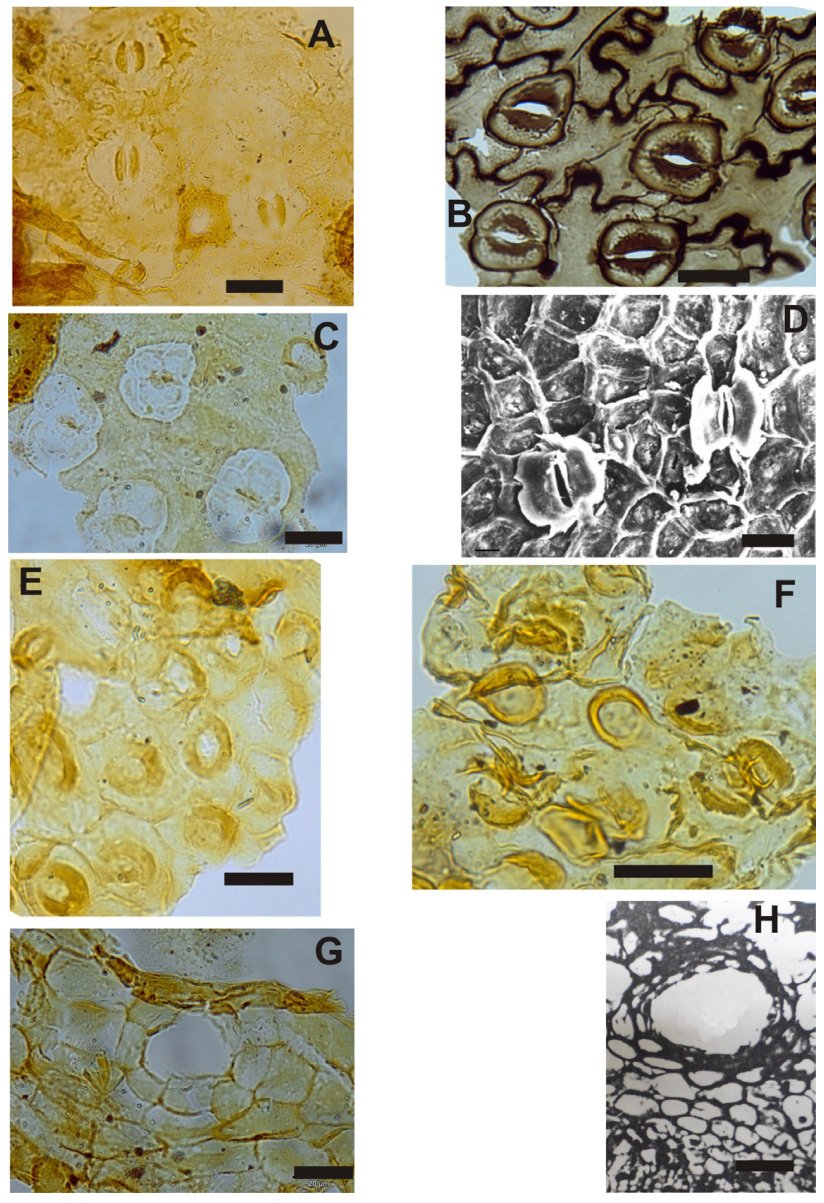

Figure 5. A - Phytoclast 14 Cuticle (Slide 12, EF=G51/3). B - Phytoclast 15 Cuticle (Slide 28.1, EF= H54/1). C - Phytoclast 16 Stomatal cells with elliptical to fusiform shape (Slide 62, EF=X53). D - Stomata of genus Sphenobaiera huangii (in Wang et al., 2005) with affinity for stomata of Phytoclast 16. E - Phytoclast 17 Cuticle (Slide 12, $\mathrm{EF}=\mathrm{F} 57 / 4)$. F - Phytoclast 18 Unicellular trichome with thicked walls (Slide 15, EF= Q51/2). G - Phytoclast 19 Secretory structure (Slide 33, EF= J33/4). H- Resin duct of Pinus (in Fahn, 1979) with affinity for Phytoclast 19. Scale bar $=20 \mu \mathrm{m}, \mathrm{EF}=$ England Finder coordinates.

Botanical affinity. Unknown.

Stratigraphic range. Unknown.

$$
\text { Phytoclast } 16 \text { (Figure 5C) }
$$

Occurrence: slide 62 .

Description. Epidermal cell impressions in cuticle are barely visible with wide stomatal structures. Stomatal cells with elliptical to fusiform shape having length and width smaller than those of subsidiary cells. The stomata may be stephanocytic or syndetocheilic with four or more differentiated cells forming a rosette around the stomatal cells as illustrated by Wang et al. (2005), Barclay et al. (2007) and Taylor et al. (2009).
Dimensions. Cuticle fragment size - $\mathrm{L}=175 \mu \mathrm{m}$, $\mathrm{W}=135 \mu \mathrm{m}$; Average cell size $-\mathrm{L}=25 \mu \mathrm{m}, \mathrm{W}=10 \mu \mathrm{m}$; Stomatal apparatus size - $\mathrm{L}=20 \mu \mathrm{m}, \mathrm{W}=30 \mu \mathrm{m}$; Stomatal guard cell size $-\mathrm{L}=6 \mu \mathrm{m}, \mathrm{W}=3 \mu \mathrm{m}$; Subsidiary cell size $\mathrm{L}=20 \mu \mathrm{m}, \mathrm{W}=13 \mu \mathrm{m}$.

Palynological association. Bisaccate pollen grains are found predominating including fare number of Araucariacites and Callialasporites in palynological record. The predominance of characteristic grains that indicate temperate environment and related to Gymnosperms are observed. Smooth and ornamented trilete spores e.g. Cicatricosisporites and Contignisporites that are undoubtedly related to Pteridophyta are recorded, besides some unidentified pollen grains.

Probable botanical affinities and their stratigraphic range. Sphenobaiera huangii (Sze) Hsu" (GinkgophytaGinkgoaceae, Permian to lower Miocene) (Figure 5D); Hedyosmum (Sw.) (Chlorantales-Chlorantaceae, Lower Cretaceous to Recent); Bennettitales (Triassic to Cretaceous); Stenochlaena (Polypodiales-Blechnaceae, Lower Cretaceous to Recent).

Stratigraphic range. Lower Cretaceous to lower Miocene.

$B$ - Cuticle with papillary epidermal cell and with trichomes Phytoclast 17 (Figure 5E)

Occurrence: slide 12 .

Description. Cuticles with approximately isodiametric epidermal cells having one papilla in the center of each cell.

Dimensions. Cuticle fragment size - $\mathrm{L}=100 \mu \mathrm{m}$, $\mathrm{W}=110 \mu \mathrm{m}$; Average cell size $-\mathrm{L}=30 \mu \mathrm{m}, \mathrm{W}=25 \mu \mathrm{m}$; Papilla size $-\mathrm{L}=18 \mu \mathrm{m}, \mathrm{W}=10 \mu \mathrm{m}$.

Palynological association. Araucariacites pollen grains are found predominant along with good number of bisaccates and Callialasporites. Palynomorphs indicate temperate climate and having relation with Gymnosperms. Smooth trilete spores and ornamented trilete spores viz. Contignisporites are also reported in the palynological sample. These trilete spores are having their origin from Pteridophyta, Lycopodiophyta or Bryophyta.

Botanical affinity. Unknown.

Stratigraphic range. Unknown. Phytoclast 18 (Figure 5F)

Occurrence: slide 15 .

Description. Tissue constituted by cells with irregular shape and slightly sinuous anticlinal walls. Cells are with unicellular trichomes having thick walls.

Dimensions. Cuticle fragment size - $\mathrm{L}=120 \mu \mathrm{m}$, $\mathrm{W}=110 \mu \mathrm{m}$; Average cell size - $\mathrm{L}=40 \mu \mathrm{m}, \mathrm{W}=20 \mu \mathrm{m}$; Papilla width - $\mathrm{L}=20 \mu \mathrm{m}, \mathrm{W}=15 \mu \mathrm{m}$.

Palynological association. Araucariacites is predominantly recorded along with many bisaccate pollen grains and Callialasporites. Predominant grains indicate temperate environment and come under plant group Gymnosperm. Ornamented trilete spores, Contignisporites and Pilosisporites are stratigraphically significant genera recorded in the studied 
slide. These trilete spores are related to Pteridophyta. Since grains with affinity for Gymnosperms are predominant, it enhances the possibility of this tissue with affinity for Gymnosperms.

Botanical affinity. Gymnosperm indet.

Stratigraphic range. Unknown.

C - Cuticle with secretory structure - resin duct

Phytoclast 19 (Figure 5G)

Occurrence: slide 33 .

Description. Secretory structure similar to conifer resin duct constituted by schizogenous cavity encircled by seven cells. Part of fragment is composed of cells having irregular shapes and straight to curved walls. The analyzed fragment does not contain conductive tissue and is inserted in the parenchyma encircled by epiderm. According to Fahn (1985), secretory structures can be constituted by one cell, group of cells or more complex secretory structures that secrete specified substances in the plants (Figure 5G). The structure recorded herein is related to resin duct of Pinus (Figure 5H).

Dimensions. Cuticle fragment size - $\mathrm{L}=160 \mu \mathrm{m}$, $\mathrm{W}=100 \mu \mathrm{m}$; Average cell size $-\mathrm{L}=28 \mu \mathrm{m}, \mathrm{W}=12 \mu \mathrm{m}$; Resin cavity size $-\mathrm{L}=60 \mu \mathrm{m}, \mathrm{W}=50 \mu \mathrm{m}$; Resin aperture cavity size - $\mathrm{L}=30 \mu \mathrm{m}, \mathrm{W}=35 \mu \mathrm{m}$; Average cell size covering resin duct $-\mathrm{L}=15 \mu \mathrm{m}, \mathrm{W}=9 \mu \mathrm{m}$.

Palynological association. Araucariacites is predominant in the palynoassemblage along with bisaccate pollen grains and Callialasporites, deciphering temperate climate. These recorded grains are related to Gymnosperms. Some smooth and ornamented trilete spores are also recorded in this slide. The abundant presence of bisaccate grains suggests high possibility of secretory structure to be associated with Coniferales.

Probable botanical affinity. Pinus (Coniferales Pinaceae) (Figure 5H).

Stratigraphic range. Triassic to Recent.

$D$ - Cuticle with only epidermal cells

Phytoclast 20 (Figsures 6A and 6B)

Occurrence: slides 1 and 2.

Description. Cuticle with elongated epidermal cells with sinuous anticlinal walls, and unknown structures at the junction between the two adjacent elongated cells in the distal portion.

Dimensions. Cuticle fragment size - $\mathrm{L}=180 \mu \mathrm{m}$, $\mathrm{W}=80 \mu \mathrm{m}$; Average cell size $-\mathrm{L}=100 \mu \mathrm{m}, \mathrm{W}=30 \mu \mathrm{m}$; Sinuosity size - $\mathrm{L}=5 \mu \mathrm{m}, \mathrm{W}=5 \mu \mathrm{m}$.

Palynological association. Araucariacites pollen grains are found predominant in the slide 1 and 2 along with large number of Callialasporites, Cicatricosisporites, Contignisporites, Klukisporites. Some smooth trilete spores and few unidentified inaperturate spores are also recorded. Comparison of present data with the available scientific literature elucidates the morphology of Phytoclast 20 as very similar to Poales (Figure 6C) and Ginkgoales. But, the presence of Poales has not been confirmed by palynological assemblage elements. Besides, its stratigraphic range is incompatible with the interval of analyzed samples. Therefore the origin of recovered tissue is possibly assigned to Ginkgophyta, because palynological constituents of this group are found in the assemblage.

Botanical affinity. Unknown.

Stratigraphic range. Unknown.

Phytoclast 21 (Figure 6D)
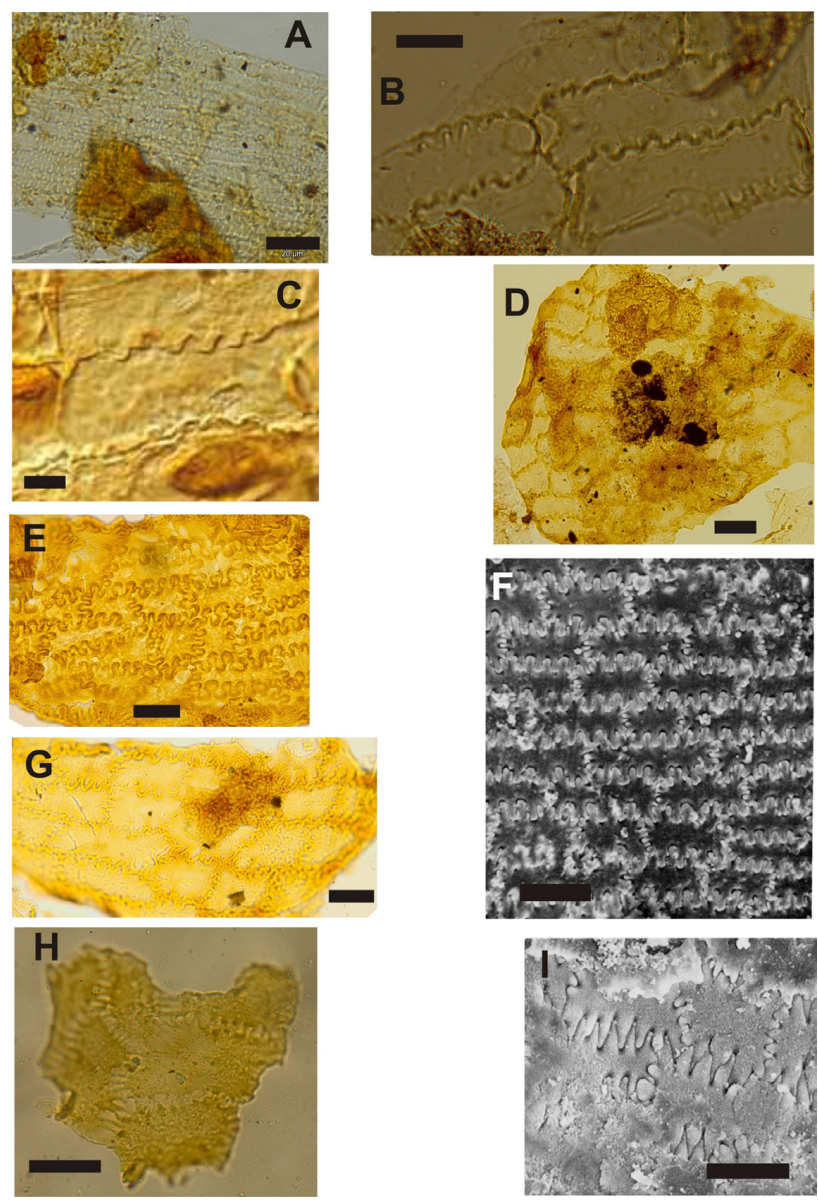

Figure 6. A - Phytoclast 20 Cuticle (Slide 1, EF= W49/4). B - Phytoclast 20 Cuticle (Slide 2, EF= T47). C - Epiderm of Poales (in Corneanu et al., 2004), whose morphology is similar to that of Phytoclast 20. D - Phytoclast 21 Cuticle (Slide 22.1, EF= L36). E - Phytoclast 22 Cuticle (Slide 12, $E F=R 47 / 2)$. F - Cuticle with very sinuous cells of grass Berriochloa (KGS, 2009), whose morphology is similar to that of Phytoclast 22. G - Phytoclast 23 Cuticle with epidermal cells and bifurcated structures in the surface (Slide 13, EF= W48/2). H - Phytoclast 24 Cuticle (Slide 7, EF= M65/3). I - Cuticle of Berriochloa with lobes acute (KGS, 2009), similar to Phytoclast 24. Scale bar $=20 \mu \mathrm{m}$, $\mathrm{EF}=$ England Finder coordinates . 
Occurrence: slide 22.1.

Description. Cuticle having epidermal cells with varied shapes and sinuous anticlinal walls.

Dimensions. Size of cuticle fragment - $\mathrm{L}=350 \mu \mathrm{m}$, $\mathrm{W}=290 \mu \mathrm{m}$; Average size of cells $-\mathrm{L}=25 \mu \mathrm{m}, \mathrm{W}=20 \mu \mathrm{m}$; Size of sinuosity - $\mathrm{L}=2 \mu \mathrm{m}, \mathrm{W}=2 \mu \mathrm{m}$.

Palynological association. Bisaccate pollen grains are found predominant along with frequent Araucariacites and Callialasporites. The present palynoassemblage indicates temperate climate and has affinity with Gymnosperms. Simple smooth and ornamented trilete spores and few unidentified pollen grains are also observed.

Botanical affinity. Unknown.

Stratigraphic range. Unknown.

$$
\text { Phytoclast } 22 \text { (Figure 6E) }
$$

Occurrence: slide 12 .

Description. Cuticle observed with elongated epidermal cells having very sinuous and thickened anticlinal walls, embedded with each other on epidermal plane. It looks like cuticles of grasses from the Cenozoic, especially Berriochloa (Poales - Poaceae) (Figure 6F) found in the Ogallala Formation (KGS, 2009). However, because of the stratigraphic incompatibility, this possibility of affinity is refused.

Dimensions. Cuticle fragment size - $\mathrm{L}=420 \mu \mathrm{m}$, $\mathrm{W}=210 \mu \mathrm{m}$; Average cell size - $\mathrm{L}=50 \mu \mathrm{m}, \mathrm{W}=25 \mu \mathrm{m}$; Sinuosity size $-\mathrm{L}=12 \mu \mathrm{m}, \mathrm{W}=6 \mu \mathrm{m}$.

Palynological association. Araucariacites is predominant in the palynoassemblage along with large number of bisaccates and Callialasporites. Recovered predominant grains are indicator of temperate climate and related to Gymnosperms. Simple smooth and ornamented trilete spores, Contignisporites are also recorded. According to published scientific data, the morphology of recovered tissue is associated with Poales. However, pollen grains associated with Poales are not recovered in the studied slide to corroborate the affinity of this tissue with Poales.

Botanical affinity. Unknown.

Stratigraphic range. Unknown.

Phytoclast 23 (Figure 6G)

Occurrence: slide 13.

Description. Cuticle with rectangular epidermal cells arranged in linear pattern with sinuous anticlinal walls. Presence of bifurcated structures is marked in some cells.

Dimensions. Cuticle fragment size - $\mathrm{L}=350 \mu \mathrm{m}$, $\mathrm{W}=150 \mu \mathrm{m}$; Average cell size $-\mathrm{L}=50 \mu \mathrm{m}, \mathrm{W}=30 \mu \mathrm{m}$; Sinuosity size $-\mathrm{L}=5 \mu \mathrm{m}, \mathrm{W}=3 \mu \mathrm{m}$

Palynological association. Pollen grains associated with Araucariacites are found predominating the palynoassemblage. Presence of a number of bisaccates and Callialasporites indicates temperate climate and these palynomorphs are related to Gymnosperms.

\section{Botanical affinity. Unknown. \\ Stratigraphic range. Unknown.}

Phytoclast 24 (Figure 6H)

Occurrence: slide 7.

Description. Cuticle with epidermal cells revealing very sinuous anticlinal walls with acute lobes. This shape of cuticle cell looks similar to Berriochloa (Poales) (Figure 6I), but this affinity is questionable because this genus occurs only from Late Cretaceous to younger strata.

Dimensions. Cuticle fragment size - $\mathrm{L}=70 \mu \mathrm{m}, \mathrm{W}=65 \mu \mathrm{m}$; Average cell size - $\mathrm{L}=4 \mu \mathrm{m}, \mathrm{W}=20 \mu \mathrm{m}$; Sinuosity size $\mathrm{L}=5 \mu \mathrm{m}, \mathrm{W}=2 \mu \mathrm{m}$.

Palynological association. Bisaccate pollen grains and Araucariacites are found in predominance in the slide 7. Callialasporites, Cicatricosisporites, Concavissimisporites and Leiotriletes constitute part of palynoassemblage. Presence of bisaccate pollen grains, Araucariacites and Callialasporites indicate temperate climate and are related to Gymnosperma. Cicatricosisporites, Concavissimisporites and Leiotriletes belong to Pteridophyta and indicate wet environment. Comparison of the collected palynological information with published scientific data suggests that morphology of the Phytoclast 24 has no relation with plant groups of the present palynological assemblage.

Botanical affinity. Unknown.

Stratigraphic range. Unknown.

Phytoclast 25 (Figures 7A and 7B)

Occurrence: slide 13 .

Description. Cuticle with rectangular epidermal cells having almost straight walls and presence of trichomes is well marked. The base of trichomes is encircled by radially arranged epidermal cells.

Dimensions. Cuticle fragment size - $\mathrm{L}=420 \mu \mathrm{m}$, $\mathrm{W}=325 \mu \mathrm{m}$; Average cell size $-\mathrm{L}=100 \mu \mathrm{m}, \mathrm{W}=12 \mu \mathrm{m}$; Trichome size - $\mathrm{L}=7 \mu \mathrm{m}$.

Palynological association. Pollen grains associated with Araucariacites are found predominant including many bisaccates and Callialasporites that are indicators of temperate climate and having relation with Gymnosperms.

Botanical Affinity. Unknown

Stratigraphic range. Unknown.

Phytoclast 26 (Figure 7C)

Occurrence: slide 10.

Description. Cuticle with irregular polygonal epidermal cells having straight and thick walls. Some cells are smaller than others present in the tissue. At the region of confluence of cell walls in some cells, a highly thickened area is observed. This cuticle is very similar to the cuticle illustrated in Corneanu et al. (2004).

Dimensions. Cuticle fragment size - $\mathrm{L}=225 \mu \mathrm{m}$, $\mathrm{W}=175 \mu \mathrm{m}$; Average cell size $-\mathrm{L}=20 \mu \mathrm{m}, \mathrm{W}=15 \mu \mathrm{m}$. 
Palynological association. Araucariacites and bisaccate pollen grains are found predominant with many Callialasporites and indicate temperate climate during the deposition of sediments. They have association with Gymnosperms. The Phytoclast 26 has a morphological characteristic that suggest affinities with Buxales (Figure7D), but palynomorphs recovered from the studied slide are not related to this plant group.

Botanical affinity. Unknown.

Stratigraphic range. Unknown.

E - Tissue of filling-parenchyma (plicate parenchyma) Phytoclast 27 (Figures 7E, 7F, 7H and 7I)
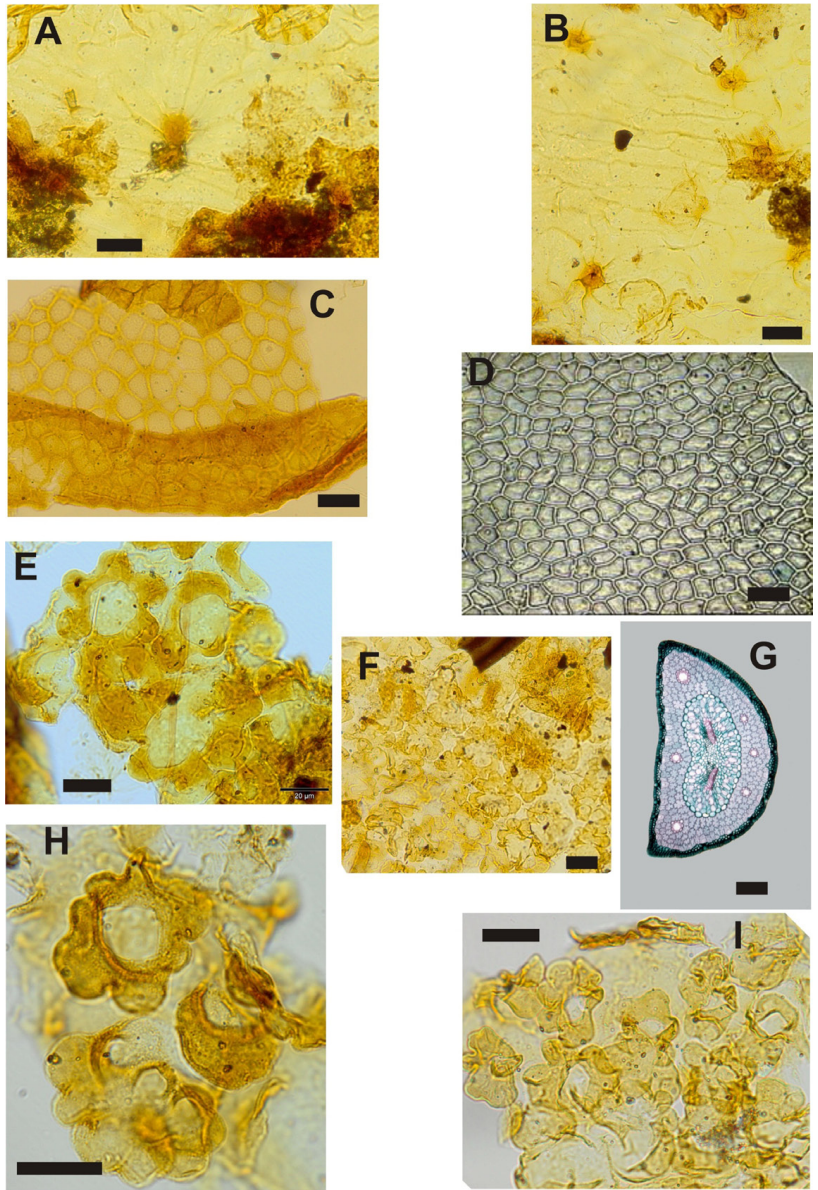

Figure 7. A, B - Phytoclast 25 Cuticle (Slide 13, EF= F68/1). C - Phytoclast 26 Cuticle (Slide 10, EF= H57/4). D - Cuticle of Buxus (Spermatophyta, Magnoliophyta, Magnoliopsida, Buxales, Buxaceae), morphologically similar to Phytoclast 26 (in Corneanu et al., 2004). E - Phytoclast 27 Plicate parenchyma (Slide 11, EF= K61/1). F - Phytoclast 27 Plicate parenchyma (Slide 12, EF= 57/4).G - Cross-section of leaf of Pinus, with affinity for Phytoclast 27. H - Phytoclast 27 Plicate parenchyma (Slide 19, EF= O59). I - Phytoclast 27 Plicate parenchyma (Slide 15, EF= Q56/2). Scale bar $=20 \mu \mathrm{m}$, EF $=$ England Finder coordinates.
Occurrences: slides 11, 12, 15 and 19 .

Description. A tissue is formed with lobed cells by the process of invagination similar to plicate parenchyma (Figures 7E, 7F, 7H and 7I). Some of the cells of this tissue are in contact with others, but other cells have spaces among them. The general tendency of this tissue is to get sponginess. The parenchymatous tissue is the main representative of fundamental tissue found in all plant organs forming a continuous tissue (Esau, 1974). The plicate parenchyma is characterized by their folded cellular walls with much reentrance. The main function of the folded walls is to increase the cell area (Esau, 1974).

Dimensions. Tissue fragment size - $\mathrm{L}=175 \mu \mathrm{m}, \mathrm{W}=160 \mu \mathrm{m}$; Average cell size - $\mathrm{L}=20 \mu \mathrm{m}, \mathrm{W}=25 \mu \mathrm{m}$.

Palynological association. Bisaccate pollen grains, Araucariacites and Callialasporites are predominant palynological elements in the slides 11, 12, 15, 19 . The predominant palynological elements in the assemblage decipher temperate climate and are related taxonomically to Gymnosperm. Ornamented trilete spores, Cicatricosisporites are also recorded in these slides. However, the predominance of palynomorphs associated with Gymnosperm corroborates the possibility of recovered parenchymal tissue to be related to Pinus.

Probable botanical affinity. Pinus sp. (Coniferales Pinaceae) (Figure 7G).

Stratigraphic range. Triassic to Recent.

\section{CONCLUSIONS}

Phytoclasts such as plant cuticles and structural tissues are preserved in the sediments during the deposition in the geological past. The preserved plant material can frequently be recovered from deposited sediments by following the standard maceration techniques in palynological laboratories. Phytoclasts, palynomorphs and other debris are frequently encountered in palynological preparation. Characteristic cuticles with distinct stomata and other fossilized tissues are of crucial significance in order to interpret the stratigraphy, palaeoecology, environment of deposition besides understanding the taxonomic status of the plant whose cuticle(s) are recovered in the palynological residue, they allow their comparison with extant plant taxa or in situ megafossil cuticles on the basis of morphotaxonomical characters preserved during the sediment deposition. In the present study, phytoclasts were considered along with palynomorphs encountered in the palynological slides to accomplish the study objectives. Many of these phytoclasts are well preserved with significant characteristics that allow their precise identification, as well as to draw their affinity with extinct or extant plant with the help of available scientific literature. Some of the phytoclasts are comparable with cuticles of living gymnosperms while others are showing only a few similarities with them but those are 
not comparable due to chronostratigraphic incompatibility, providing an insight of the evolutionary history of such taxa and geological age of deposition. The phytoclasts are grouped here into five categories based on preserved structures in them such as stomata, papillary epidermal cell with trichomes, secretory structure - resin duct, epidermal cells, filling-parenchyma (plicate parenchyma). Analyses of spores and pollen grains present in the palynoassemblage of the given depth in a lithological sequence with phytoclasts, can infer more accurate and precise botanical affinities of investigated phytoclasts. The interpretation of contents of fossil flora was more reliable when there was a coincidence between the plant family indicated by palynological assemblage and that suggested by phytoclast morphology. This indicates the coexistence of the mother plants and their derived palynomorphs. Morphological attributes of the phytoclasts indicated the affinity with the various taxa viz. Pinus (Coniferales-Pinaceae), Frenelopsis (ConiferalesCheirolepidiaceae), Pseudofrenelopsis (ConiferalesCheirolepidiaceae), Nilssoniopteris (Bennettitales), Cryptomeria (Coniferales-Cupressaceae), Cephalotaxus (Coniferales-Taxaceae), Sphenobaiera huangii (GinkgophytaGinkgoaceae), Hedyosmum (Chlorantales-Chlorantaceae), Stenochlaena (Polypodiales-Blechnaceae), showing the contemporaneous palaeovegetation during the deposition and their contribution to the ecosystem at the base by means of photochemical process, the photosynthesis as primary producer. In spite of the structural similarity of the fossilized cuticles with Pteridospermales and Sphenophyllales, they are not taken in consideration as components of the palaeovegetation because of their extinction during the Triassic. While most of the phytoclasts are identified on the basis of morphological similarities of their cuticular structures along with palynomorphs support Late Jurassic-Early Cretaceous age of the sediments in Gangapur Formation. The overall palynological composition and phytoclasts indicate the cold and wet environment of deposition.

Phytoclasts of Sriperunbdur Foramation show close morphological similarities with generalized cuticular structures represented by Poales and Ginkgoales. They are supposed to have botanical affinity with Poales or Ginkgoales. But, the presence of Poales in the sediments has not been confirmed by palynological constituents. Besides, their geological age range does not match with the geological age of studied phytoclast. Therefore the origin of recovered tissue is assigned to have similarity with Ginkgophyta while its affinity with any taxa could not be confirmed. The palynoassemblage is predominated by Araucariacites and Callialasporites, and the spores are represented by Cicatricosisporites, Contignisporites, Klukisporites with triletes and inaperturate spores. The sediments are assigned Late Jurassic-Early Cretaceous age with cold and wet environment during deposition.
In Rajmahal Basin, the cellular shapes in the cuticle are shown to have similarities with Berriochloa (Poales). But Poales are not reported to have similar geological age of the studied phytoclast as they have Early Cretaceous age. This may indicate a mere morphogical convergence on epidermal tissues between two distinct plant groups. The predominance of Araucariacites and bisaccates in palynoassemblage with Cicatricosisporites, Concavissimisporites and Leiotriletes indicate cold and wet climatic conditions in the depositional site.

\section{ACKNOWLEDGEMENTS}

The authors thank Dr. Sunil Bajpai (Director of BSIP-Birbal Sahni Institute of Palaeosciences, Lucknow, India) for granting permission for Sarah G. Duarte to carry out the present work; Dr. Naresh Mehrotra for establishing initial contact between Sarah and her supervisor Dr. Neerja Jha (BSIP); CAPES (Coordenação de Aperfeiçoamento de Pessoal de Nível Superior, Brazil) for financial support; UFRJ (Universidade Federal do Rio de Janeiro) for the permission to travel to India; Prof. Maria Judite Garcia and Prof. Mary Elizabeth Bernardes-de-Oliveira (Universidade de São Paulo, Brazil) for useful comments and suggestions that contributed significantly to improve this paper; Dr. Ricardo Vieira (UFRJ) for bibliographical suggestions; Dr. Marcos Leal and Msc. Nícia Junqueira (UFRJ) for suggestions and for help in taxonomic identification.

\section{REFERENCES}

Anzotegui, L. M. (1980). Cuticulas del Terciario Superior de la provincia de Corrientes. Republica Argentina. II Congreso Argentino de Paleontontologia y Bioestratigraphia y I Congreso Latin American de Paleontologia, 1978. v. 3, p. 141-167. Buenos Aires.

Arai, M., Duarte, S. G. (2010). Tricomas fósseis como nova categoria de palinomorfos lato sensu: sua classificação preliminar e aplicabilidade na Bioestratigrafia. Boletim do Museu Paraense Emílio Goeldi Ciências Naturais, 5(1), 13-112.

Banerji, J. (2000). Megafloral diversity of the upper Gondwana sequence of the Rajmahal Basin, India. Journal of African Earth Sciences, 31(1), 133-144.

Barclay, R., Mcelwain, J., Dilcher, D., Bradley, S. (2007). The Cuticle Database: Developing an interactive tool for taxonomic and Palaeoenvironmental study of the fossil cuticle record. Cour. Forsch-Inst. Seckenberg, 258, 39-55.

Corneanu, G. C., Corneanu, M., Bercu, R. (2004). Comparison between some morpho-anatomical features at fossil vegetal 
species and at their actual correspondent species. Studia Universitatis Babeş-Bolyai. Geologia, XLIX(2), 77-84.

Dev, S., Rajanikanth, A. (1988). The Gangapur Formation: Fossil Flora and Stratigraphy. Geophytology, 18(1), 1-27.

Duarte, S. G., Arai, M. (2008). Esclerócitos: estudo comparativo entre os fósseis e os de plantas viventes. XII Simpósio Brasileiro de Paleobotânica e Palinologia. 57. Florianópolis: UFSC/UFRGS/ALPP.

Duarte, S. G., Arai, M. (2010). Esclerócitos: proposta de uma nova categoria de palinomorfos lato sensu. Revista Brasileira de Paleontologia, 13(1), 67-76. http://dx.doi. org/10.4072/rbp.2010.1.08.

Esau, K. (1974). Anatomia das plantas com sementes (1a ed.). São Paulo: Edgard Blucher LTDA. 293 p.

Esau, K. (1977). Anatomy of seed plants (2a ed.). New York: John Wiley \& Sons. 550 p.

Fahn, A. (1979). Secretory tissues in plants. London: Academic Press. 302 p.

Fahn, A. (1985). Plant anatomy (3a ed.). Madrid: Ediciones Piramide. 559 p.

Fahn, A. (1990). Plant anatomy. New York: Pergamon Press. 588 p.

Jha, N. (2008). Permian-Triassic palynofloral transition in the sattupalli area, chintalapudi sub-basin, Godavari Graben, Andhra Pradesh, India. Journal of Palaeontological Society of India, 53(2), 159-168.

Jha, N., Chary, M. B., Aggarwal, N. (2012). Permian Triassic palynofloral transition in Chintalapudi area, Godavari Graben, Andhra Pradesh, India. Journal of Earth System Science, 121(5), 1287-1303.

Jha, N., Sabina, P., Aggarwal, N., Mahesh, S. (2014). Late Permian Palynology and depositional environment of Chintalapudi sub basin, Pranhita-Godavari basin, Andhra Pradesh, India. Journal of Asian Earth Sciences, 79, 382-399. http://dx.doi.org/10.1016/j.jseaes.2013.10.010.

Juchniewicz, K. (1975). The fossil flora from Turow near car Bogatynia studied by cuticular analysis, I. Cuticulae dispersae in clays. Place Muzeum Ziemi, 24, 64-115.

Kansas Geological Survey (KGS). (2009). Late Cenozoic Grasses. Accessed on: June 4, 2014, <http://www.kgs.ku.edu/ Publications/Bulletins/218/08_plates.html>.

Khar, R., Singh, R. S. (2003). First occurrence of fossil paraphyses resembling Acrostichum Linn. From the Lalitpur Intertrappean sediments (Palaeocene), Uttar Pradesh, India. The Palaeobotanist, 52, 81-85.

Kovach, W. L., Dilcher, D. L. (1984). Dispersed Cuticles from the Eocene of North America. Botanical Journal of the Linnean Society, 88, 63-104.
Lakhanpal, R. N. (1945). Microfossils from cores recovered from boreholes in the saline series at Khewra in the Pujab salt range. Palaeobotanist, 1, 155-166.

Lal, N. K., Siawal, A., Kaul, A. K. (2009). Evolution of East Coast of India - A Plate Tectonic Reconstruction. Journal of the Geological Society of India, 73, 249-260.

Ma, Q. W., Li, C. S., Li, F. L. (2007). Epidermal structures of Cryptomeria japonica and implications to the fossil record. Acta Palaeobotanica, 47(1), 281-289.

Metcalfe, C. R., Chalk, L. (1979). Anatomy of the dicotyledons. Systematic anatomy of leaf and stem, with a brief history of the subject ( $2 \mathrm{a}$ ed., v. 1). Oxford: Clarendon Press.

Pflanzenfossilien. (2012). Quadrocladus. Accessed on: June 4, 2014, <http://pflanzenfossilien.homepage.t-online. de/Quadrocladus\%20solmsii.html >.

Pott, C., Krings, M. (2010). Gymnosperm foliage from the Upper Triassic of Lunz, Lower Austria: An Annotated check list and identification key. Geo Alp, 7(S), 19-38.

Sitholey, R. V., Sah, S. C. D., Dube, S. N. (1954). Plant Microfossils from a Carbonaceous shale (krols) near Naini Tal. Journal of Scientific and Industrial Research, 13B(6), 450-451.

Sorkhabi, R. (2008). Putting India on the world's petroleum map. Geotimes. Accessed on: July 16, 2014, < http://www. geotimes.org/feb08/article.html?id=feature_oil.html>

Srivastava, R., Krassilov, V. A. (2012). Revision of Early Cretaceous angiosperm remains from the Rajmahal Basin, India, with notes on the palaeoecology of the Pentoxylon plant. Cretaceous Research, 33, 66-71. http://dx.doi.org/10.1016/j. cretres.2011.08.003.

Taylor, T. N., Taylor, E. L., Krings, M. (2009). Paleobotany: the biology and evolution of fossil plants. $2^{\mathrm{a}}$ ed. Burlington, London, San Diego, New York: Elsevier/Academic Press.

Tewari, R., Kumar, M., Prakash, A., Shukla, M., Srivastava, G. P. (2001). Dispersed Angiosperm cuticles from a lignitic clay bed, Sindhudurg Formation (Miocene), Maharashtra: an interpretation on taxonomy, biodegradation and environment of deposition. The Palaeobotanist, 50(2,3), 369-380.

Universitat Muenster. (2014). Plant Cuticles and some of their applications in palaeobotany. Accessed on: June 4, 2014, <http://www.unimuenster.de/GeoPalaeontologie/ Palaeo/Palbot/cuticles.htm>

Wang, Y., Guignard, G., Thévenard, F., Dilcher, D., Barale, G., Mosbrugger, V., Yang, X., Mei, S. (2005). Cuticular anatomy of Sphenobaiera Huangii (Ginkgoales) from the Lower Jurassic of Hubei, China. American Journal of Botany, 92(4), 709-721. 
Watson, J. (1977). Some Lower Cretaceous conifers of the Cheirolepidiaceae from the U.S.A. and England. Palaeontology, 20(4), 715-749.

Watson, L., Dallwitz, M. J. (2009). The families of Gymnospermus. Accessed on: June 4, 2014, <http://deltaintkey.com/gymno/www/cephalot.htm>.
Yang, X., Guignard, G., Theévenard, F., Wang, Y. D., Barale, G. (2009). Leaf cuticle ultrastructure of Pseudofrenelopsis dalatzensis (Chow et Tsao) Cao ex Zhou (Cheirolepidiaceae) from the Lower Cretaceous Dalazi Formation of Jilin, China. Review of Palaeobotany and Palynology, 153, 8-18. http:// dx.doi.org/10.1016/j.revpalbo.2008.06.002. 
Appendix. Slides studied in this work

MJR = Chintalapudi Sub-basin (Dubrajpur Formation)

PBS = Palar Basin (Sriperumbudur Formation)

RJS = Rajmahal Basin (Dubrajpur Formation)

Depth in meters $(\mathrm{m})$

Slide 1 - PBS-100 117432, $520.10 \mathrm{~m}$.

Slide 2 - PBS-39 11733, $165.40 \mathrm{~m}$.

Slide 7 - RJR - 21915, Rajmahal B.

Slide 10 - MJR - $11 \mathrm{KOH}$ I Alkali, $36.50 \mathrm{~m}$.

Slide 11 - MJR - $11 \mathrm{KOH}, 36.50 \mathrm{~m}$.

Slide 12 - MJR - $11 \mathrm{H} 2,36.50 \mathrm{~m}$.

Slide 13 - 1 E MJR - $11 \mathrm{KOH}, 36.50 \mathrm{~m}$.

Slide 15 - MJR - $11 \mathrm{KOH}, 82.50 \mathrm{~m}$.

Slide 18 - MJR - $11 \mathrm{KOH}, 82.50 \mathrm{~m}$.

Slide 19 - MJR - $11 \mathrm{KOH}, 49.50 \mathrm{~m}$.

Slide 20 - MJR - $11 \mathrm{KOH}, 49.50 \mathrm{~m}$.

Slide 22.1 - MJR-11 KOH, $49.50 \mathrm{~m}$.

Slide 27 - MJR - $11 \mathrm{KOH}, 46.40 \mathrm{~m}$.

Slide 28 - MJR - $11 \mathrm{KOH}, 46.40 \mathrm{~m}$.

Slide 28.1 - MJR - $11 \mathrm{KOH}, 46.40 \mathrm{~m}$.

Slide 30 - MJR - $11 \mathrm{KOH}, 46.40 \mathrm{~m}$.

Slide 33 - MJR - $11 \mathrm{KOH}, 37.50 \mathrm{~m}$.

Slide 37 - MJR - $11 \mathrm{KOH}, 37.50 \mathrm{~m}$.

Slide 51.1 - 7 - after MJR - $11 \mathrm{KOH}, 64.50 \mathrm{~m}$.

Slide 51.2 - 7 after MJR - $11 \mathrm{KOH}, 64.50 \mathrm{~m}$.

Slide 52 - After KOH MJR-11, 52.50 m.

Slide 61 - MJR - 11 after KOH, $46.70 \mathrm{~m}$.

Slide 62 - F after MJR - $11 \mathrm{KOH}, 46.70 \mathrm{~m}$. 